\title{
PROXIMAL DISABILITY AND SPINAL DEFORMITY INDEX IN PATIENTS WITH PROXIMAL FEMUR FRACTURES
}

\author{
INCAPACIDADE FUNCIONAL E ÍNDICE DE DEFORMIDADE ESPINAL \\ EM PACIENTES COM FRATURA DO FÊMUR
}

\author{
DISCAPACIDAD E ÍNDICE DE DEFORMIDAD ESPINAL EN PACIENTES CON \\ FRACTURA DE LA PARTE PROXIMAL DEL FÉMUR
}

Sylvio Mistro Neto ${ }^{1}$, Marcelo Italo Risso Neto¹, Guilherme Rebechi Zuiani ${ }^{1}$ Roberto Rossanez', Gabriel Gomes Freitas de Castro ${ }^{1}$, Ivan Guidolin Veiga ${ }^{1}$, Wagner Pasoualini ${ }^{1}$, Marcos Antônio Tebet ${ }^{1}$, Élcio Landim¹ ${ }^{1}$ William Dias Belangero ${ }^{1}$, Paulo Tadeu Maia Cavali ${ }^{1}$

\begin{abstract}
Objective: To evaluate the quality of life related to the spine in patients with proximal femoral fractures. Methods: Study conducted in a tertiary public hospital in patients with proximal femoral fractures caused by low-energy trauma, through the Oswestry Disability Index questionnaire to asses complaints related to the spine at the time of life prior to the femoral fracture. The thoracic and lumbar spine of patients were also evaluated applying the radiographic index described by Gennant (Spinal Deformity Index), which assesses the number and severity of fractures. Results: Seventeen subjects completed the study. All had some degree of vertebral fracture. Patients were classified in the categories of severe and very severe disability in the questionnaire about quality of life. It was found that the higher SDI, the better the quality of life. Conclusion: There is a strong association of disability related to the spine in patients with proximal femoral fracture, and this complaint must be systematically evaluated in patients with appendicular fracture.
\end{abstract}

Keywords: Femoral fractures; Quality of life; Osteoporosis; Spinal fractures.

\section{RESUMO}

Objetivo: Avaliar a qualidade de vida relacionada com a coluna vertebral em pacientes com fratura da parte proximal do fêmur. Métodos: Estudo realizado em um hospital público terciário em pacientes com fraturas do fêmur proximal causado por trauma de baixa energia, por meio de aplicação do questionário Oswestry Disability Index, para avaliar as queixas relacionadas com a coluna vertebral no momento de vida prévio à fratura femoral. Avaliaram-se também as colunas torácica e lombar dos pacientes aplicando-se o índice radiográfico descrito por Gennant (Spinal Deformity Index), que avalia o número e a gravidade das fraturas. Resultados: Dezessete sujeitos concluíram o estudo. Todos apresentaram algum grau de fratura vertebral. Os pacientes enquadraram-se nas categorias de incapacidade severa e muito severa do questionário de qualidade de vida. Verificou-se que quanto maior o SDI, melhor a qualidade de vida. Conclusão: Há forte associação de incapacidade relacionada à coluna vertebral em pacientes e fratura do fêmur proximal, devendo esta queixa ser avaliada sistematicamente em pacientes com a fratura apendicular.

Descritores: Fratura do fêmur; Qualidade de vida; Osteoporose; Fraturas da coluna vertebral.

\section{RESUMEN}

Objetivo: Evaluar la calidad de vida relacionada con la columna vertebral en pacientes con fracturas de la parte proximal del fémur. Métodos: Estudio realizado en un hospital público terciario en pacientes con fracturas femorales proximales causadas por un traumatismo de baja energía, a través del cuestionario Oswestry Disability Index para evaluar las quejas relacionadas con la columna vertebral en el momento de la vida antes de la fractura femoral. También se evaluaron columna torácica y lumbar de los pacientes por el índice radiográfico descrito por Gennant (Índice de deformidad de la columna), que evalúa el número y la gravedad de las fracturas. Resultados: Diecisiete sujetos completaron el estudio. Todos tenían algún grado de fractura vertebral. Los pacientes fueron clasificados en las categorías de discapacidad grave y severa del cuestionario sobre calidad de vida. Se encontró que cuanto mayor sea el SDI, mejor será la calidad de vida. Conclusión: Hay una fuerte asociación de la discapacidad relacionada con la columna vertebral en pacientes con fractura del fémur proximal y esta queja debe ser evaluada de forma sistemática con fractura apendicular.

Descriptores: Fracturas del fémur; Calidad de vida; Osteoporosis; Fracturas de la columna vertebral.

\section{INTRODUCTION}

Osteoporosis is a global public health issue. ${ }^{1}$ It is characterized as a diffuse bone disease with a decrease in bone mass and a change in the microarchitecture of the bone tissue, with a consequent increase in fragility and susceptibility to fracture from low energy traumas. ${ }^{2}$

This disease is responsible for more than 1.5 million fractures per year in the USA. ${ }^{3}$ Approximately $40 \%$ of Caucasian women and $13 \%$ of men above 50 years of age have at least one clinically-recognized fracture from osteoporosis in the hip, wrist, or spine. ${ }^{4,5}$ The expenditure of public health resources on the consequences of osteoporosis is very high, with approximately 17 billion dollars spent in 2005 in the USA, a figure that is expected to triple by $2010 .^{6,7}$ Hip and spine fractures are hallmarks of insufficiency fractures, the two most com-

1. Universidade Estadual de Campinas, UNICAMP. Campinas, SP. Brazil.

Study conducted by the Spine Surgery Group of the Department of Orthopedics and Traumatology of the Faculdade de Ciências Médicas da Universidade Estadual de Campinas (Unicamp), Campinas, SP, Brazil.

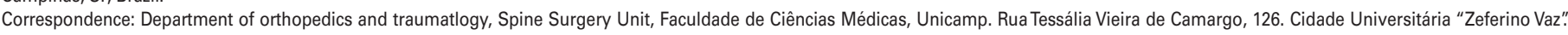
Campinas, SP, Brazil. 13083-887 mrisso@mpc.com.br, sylvio.mistro@gmail.com 
mon injuries caused by osteoporosis, among which spine fractures are responsible for approximately $50 \%$ of all osteoporotic fractures, totaling between 700,000 and 750,000 injuries in the USA annually. ${ }^{3}$

Hip fractures are clinically easily recognizable by the immediate functional disability that they generate. On the other hand, insufficiency fractures of the spine, especially the thoracic and lumbar segments, can take more time to recognize clinically and radiologically, and may not be immediately identified in up to $75 \%$ of cases..$^{8-10}$ The presence of a vertebral fracture is a risk factor for other fractures in other parts of the skeleton, increasing fivefold the risk of a new vertebral fracture and tripling the risk of a non-vertebral fracture. ${ }^{11-14}$

The impact on quality of life of patients with osteoporosis is primarily related to the consequences of the fractures, which, in the case of vertebral fractures, bring pain, deformity, weight loss, physical dysfunction, immobility, loss of lung capacity, and gastroesophageal reflux, among others. Abnormality in physical activity and changes in appearance contribute to social isolation, loss of self-esteem, and depression. This impact can be evaluated using tools that assess the state of health of patients by means of self- or interviewer-administered questionnaires. ${ }^{1,15,16}$ Among the questionnaires that evaluate the quality of life, we cite the Oswestry Disability Index (ODI). ${ }^{16}$

The spine can be evaluated using various radiographic methods, among them the Spinal Deformity Index (SDI) described by Minnie and Gennant, which assesses both the number of fractured vertebrae and their degree of seriousness via radiographs of the thoracolumbar spine, allowing the prevalent fractures to be evaluated in an initial assessment, and incidental fractures in serial exams. ${ }^{17}$

The objective of this study is to evaluate spine-related disability prior to the event of an appendicular fracture through a quality of life questionnaire, using radiographic methods to confirm possible alterations in the spine.

\section{MATERIALS AND METHODS}

In the period May 2012 to March 2014, patients admitted to a tertiary public hospital who had proximal femoral fractures (femoral neck, transtrochanteric, or subtrochanteric), originating from low-energy trauma, underwent definitive treatment, had their thoracic and lumbar spines $\mathrm{x}$-rayed, and were given a quality of life questionnaire, the Oswestry Disability Index, which was filled out with regressive information from the period immediately prior to the hip fracture. All the patients agreed to and signed the Informed Consent Form, which was approved by the Institutional Review Board, under registration number CAAE 04559312.0000.5404.

The exclusion criteria of the study were patients less than 50 years of age, patients with pathological fractures caused by tumors, victims of high energy trauma, patients who had undergone surgical treatment for any disease of the thoracic or lumbar spine, patients with congenital spine deformities, patients with scoliosis, patients with insufficient understanding to fill out the questionnaire, and patients who refused to participate in the study or sign the Informed Consent Form of the study. For the application of the ODI questionnaire, the patient was instructed to respond based on the presence or absence of back or leg pain during the period immediately prior to the hip fracture. The questionnaire is made up of 10 questions, each with six statements, in order to identify limitations in nine day-to-day activities, and in the sex life. The final score measures the degree of disability as a percentage, classified as minimum, moderate, severe, very severe, and exaggerated symptoms, as illustrated in Attachment 1.

Radiographs were taken in posteroanterior and lateral views, in separate instances, for the thoracic and lumbar spines, in order to evaluate deformities in the coronal and sagittal planes, respectively. Scoliosis and changes that led to the suspicion of neoplasia were investigated in the posteroanterior radiograph. In the lateral radiograph the spinal deformity resulting from vertebral compression fractures was evaluated.

In the lateral radiographs, the T4 to $L 4$ vertebrae were scored individually on a scale from one to three. This method is not usable in the presence of congenital deformity, scoliosis, previous bone surgeries of the spine, or the presence of vertebral tumors. As illustrated in Figure 1, a vertebra classified with a grade 1 fracture presents a reduction of $25 \%$ in the height of one of the walls, grade 2 between $25 \%$ and $40 \%$, and grade 3 more than $40 \%$. The sum of the results classifies the spine with an index that represents the Spinal Deformity Index, shown in Figure 2.

\section{RESULTS}

The study consisted of 17 patients; 11 female and 6 male. The average age was 75.4 years, as shown in Table 1. SPSS 20.0 (SPSS, Inc., Chicago, IL, USA) was used for the statistical analysis, with the tests conducted at a significance of $5 \%$.

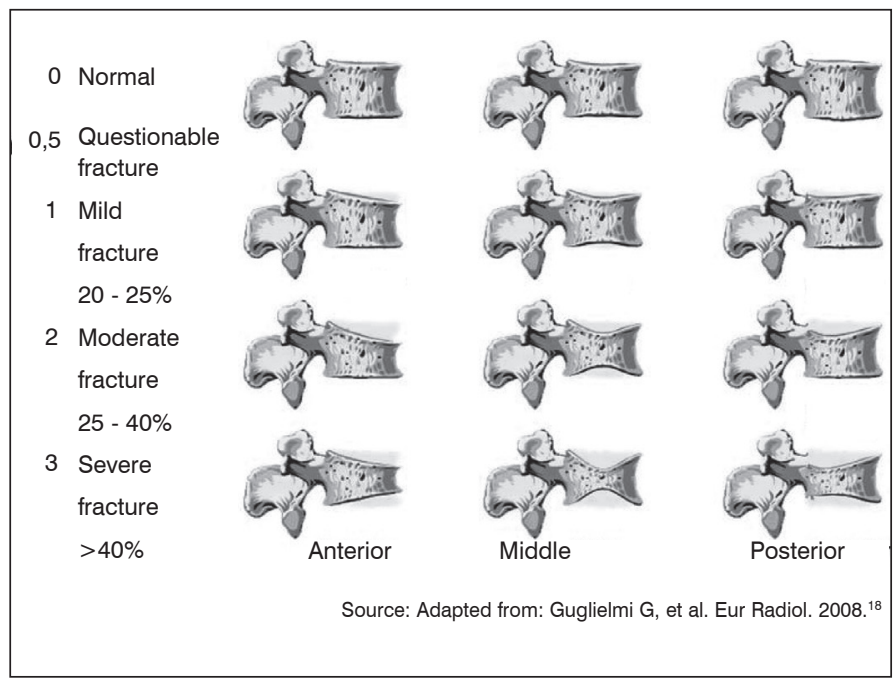

Figure 1. Gradation of vertebral fractures according to the Gennant method.

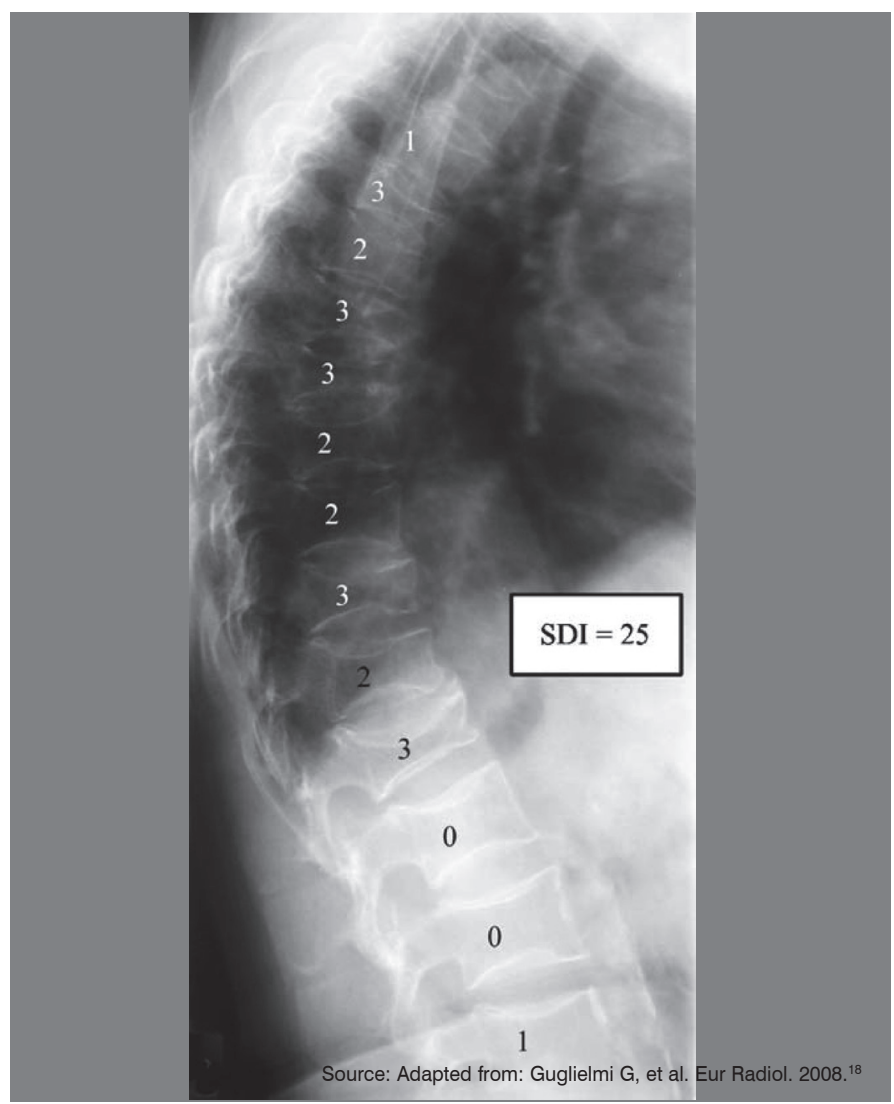

Figure 2. SDI calculation model in a spine $x$-ray. 
None of the patients in this study were being treated for osteoporosis and none had any condition prior to the fracture of the femur that could have masked the results of the ODI questionnaire.

The ODI results showed that 11 patients (64.7\%) had severe disability and 6 patients (35.3\%) had very severe disability, as can be seen in Table 2.

A correlation of the sex of the patient with the ODI results was performed by applying the Mann-Whitney test. ${ }^{19}$ No statistically significant relationship $(p=0.062)$ was observed, but the test suggested that male patients had lower quality of life scores as compared to the females, as shown in Table 3.

The 17 patients all had spine fractures evaluated by the SDI and L1 was the vertebra where some grade of fracture occurred most often, in 13 patients as shown in Table 4.

In applying the Spearman correlation, ${ }^{19}$ which correlates the result of the ODI and the age of the patient with the individual score of each vertebra and with the SDI, we observed a statistically significant inverse relationship between the score of the fracture and the ODI $(r=-0.528$ and $p=0.029)$ in $L 3$ and a statistically significant direct correlation of age with individual score was observed in T7 $(r=0.560$ and $p=0.019)$.

We also observed a statistically significant inverse correlation of the ODI with the SDI. The greater the SDI, the lower the ODI of the patient $(r=-0.628$ and $p=0.007)$, as shown in Table 5 .

In order to confirm whether the grade of disability shown by the ODI has a relationship to the SDI, the Mann-Whitney test ${ }^{19}$ was applied, in which it was shown that patients with very severe disability have SDI values that are statistically significantly lower than patients with severe disability, with $p=0.001$, as shown in Table 6 .

The ROC curve was created, the best SDI cutoff point to discriminate the quality of life categories of quality of life was established, the SDI cutoff point and its associated sensitivity and specificity were provided. Thus, we confirmed that the SDI shows good discrimination of the quality of life categories, since it presents almost $100 \%$ of the area of the graph, and a cutoff point for the SDI can be established at 5.5 with sensitivity of $90.9 \%$ and specificity of $100 \%$, shown in Figure 3 and Table 7.

Table 1. Description of patient's age and sex.

\begin{tabular}{c|c}
\hline Variable & Description (N = 17) \\
\hline Sex, $\mathrm{n}(\%)$ & \\
\hline Female & $11(64.7)$ \\
\hline Male & $6(35.3)$ \\
\hline Age (years) & \\
\hline Average (SD) & $75.4(7.6)$ \\
\hline Mean (min; max) & $77(64 ; 89)$ \\
\hline
\end{tabular}

Table 2. Description of the patients' degree of disability.

\begin{tabular}{c|c}
\hline Oswestry & $\mathbf{N}(\%)$ \\
\hline Severe disability & $11(64.7)$ \\
\hline Very severe disability & $6(35.3)$ \\
\hline Average (DP) & $36.6(12.3)$ \\
\hline Mean (min;max) & $31(22 ; 56)$ \\
\hline
\end{tabular}

Table 3. Description of Oswestry according to sex and result of the comparison between the sexes.

\begin{tabular}{c|c|c|c|c|c|c|c}
\hline Sex & Average & SD & Median & Minimum & Maximum & $\mathbf{N}$ & $\mathbf{p}$ \\
\hline Female & 40.0 & 11.4 & 35 & 26 & 56 & 11 & \multirow{2}{*}{0.062} \\
\hline Male & 30.3 & 12.3 & 26.5 & 22 & 55 & 6 & \\
\hline
\end{tabular}

Table 4. Description of the scores for each vertebra and of the SDI.

\begin{tabular}{|c|c|}
\hline Vertebra & Description $(\mathrm{N}=17)$ \\
\hline \multicolumn{2}{|l|}{$\mathrm{T} 4$} \\
\hline 0 & $10(58.8)$ \\
\hline 1 & $3(17.6)$ \\
\hline 2 & $3(17.6)$ \\
\hline 3 & $1(5.9)$ \\
\hline \multicolumn{2}{|l|}{ T5 } \\
\hline 0 & $11(64.7)$ \\
\hline 1 & $4(23.5)$ \\
\hline 2 & $2(11.8)$ \\
\hline \multicolumn{2}{|l|}{ T6 } \\
\hline 0 & $10(58.8)$ \\
\hline 1 & $6(35.3)$ \\
\hline 2 & $1(5.9)$ \\
\hline \multicolumn{2}{|l|}{ T7 } \\
\hline 0 & $10(58.8)$ \\
\hline 1 & $2(11.8)$ \\
\hline 2 & $3(17.6)$ \\
\hline 3 & $2(11.8)$ \\
\hline \multicolumn{2}{|l|}{ T8 } \\
\hline 0 & 9 (52.9) \\
\hline 1 & $7(41.2)$ \\
\hline 2 & $1(5.9)$ \\
\hline \multicolumn{2}{|l|}{ T9 } \\
\hline 0 & $11(64.7)$ \\
\hline 1 & $4(23.5)$ \\
\hline 2 & $2(11.8)$ \\
\hline \multicolumn{2}{|l|}{ T10 } \\
\hline 0 & $10(58.8)$ \\
\hline 1 & $4(23.5)$ \\
\hline 2 & $2(11.8)$ \\
\hline 3 & $1(5.9)$ \\
\hline \multicolumn{2}{|l|}{ T11 } \\
\hline 0 & $10(58.8)$ \\
\hline 1 & $5(29.4)$ \\
\hline 2 & $1(5.9)$ \\
\hline 3 & $1(5.9)$ \\
\hline \multicolumn{2}{|l|}{ T12 } \\
\hline 0 & $7(41.2)$ \\
\hline 1 & $8(47.1)$ \\
\hline 2 & $1(5.9)$ \\
\hline 3 & $1(5.9)$ \\
\hline \multicolumn{2}{|l|}{ L1 } \\
\hline 0 & $4(23.5)$ \\
\hline 1 & $10(58.8)$ \\
\hline 2 & $3(17.6)$ \\
\hline \multicolumn{2}{|l|}{ L2 } \\
\hline 0 & $7(41.2)$ \\
\hline 1 & $9(52.9)$ \\
\hline 2 & $1(5.9)$ \\
\hline \multicolumn{2}{|l|}{ L3 } \\
\hline 0 & $10(58.8)$ \\
\hline 1 & $5(29.4)$ \\
\hline 2 & $1(5.9)$ \\
\hline 3 & $1(5.9)$ \\
\hline \multicolumn{2}{|l|}{ L4 } \\
\hline 0 & $11(64.7)$ \\
\hline 1 & $6(35.3)$ \\
\hline \multicolumn{2}{|l|}{ SDI } \\
\hline Average (SD) & $8.1(4.7)$ \\
\hline Mean (min; max.) & $8(2 ; 18)$ \\
\hline
\end{tabular}


Table 5. Correlation of Oswestry and of age with the score for fracture in each vertebra and with the SDI.

\begin{tabular}{ccccc}
\hline \multirow{2}{*}{ Variable } & \multicolumn{3}{c}{ Oswestry } & Age \\
\cline { 2 - 5 } & Correlation & $\mathbf{p}$ & Correlation & $\mathbf{p}$ \\
\hline Age (years) & -0.240 & 0.353 & & \\
\hline T4 & -0.385 & 0.127 & 0.322 & 0.208 \\
\hline T5 & -0.435 & 0.081 & 0.466 & 0.060 \\
\hline T6 & -0.169 & 0.516 & 0.115 & 0.662 \\
\hline T7 & -0.186 & 0.474 & 0.560 & 0.019 \\
\hline T8 & -0.432 & 0.083 & 0.244 & 0.345 \\
\hline T9 & -0.352 & 0.166 & -0.054 & 0.836 \\
\hline T10 & -0.199 & 0.444 & 0.302 & 0.239 \\
\hline T11 & -0.254 & 0.325 & 0.209 & 0.421 \\
\hline T12 & -0.440 & 0.077 & 0.037 & 0.888 \\
\hline L1 & -0.194 & 0.456 & -0.145 & 0.578 \\
\hline L2 & -0.163 & 0.531 & 0.043 & 0.870 \\
\hline L3 & -0.528 & 0.029 & 0.185 & 0.477 \\
\hline L4 & -0.327 & 0.200 & 0.214 & 0.409 \\
\hline SDI & -0.628 & 0.007 & 0.422 & 0.091 \\
\hline
\end{tabular}

Table 6. Description of SDI according to the quality of life category and the result of the comparison.

\begin{tabular}{c|c|c|c|c|c|c|c}
\hline Oswestry & Average & SD & Mean & Minimum & Maximum & $\mathbf{~ N}$ & $\mathbf{p}$ \\
\hline $\begin{array}{c}\text { Severe } \\
\text { disability }\end{array}$ & 10.6 & 3.8 & 12 & 4 & 18 & 11 & \multirow{2}{*}{0.001} \\
\cline { 1 - 1 } $\begin{array}{c}\text { Very severe } \\
\text { disability }\end{array}$ & 3.5 & 1.0 & 3.5 & 2 & 5 & 6 & \\
\hline
\end{tabular}

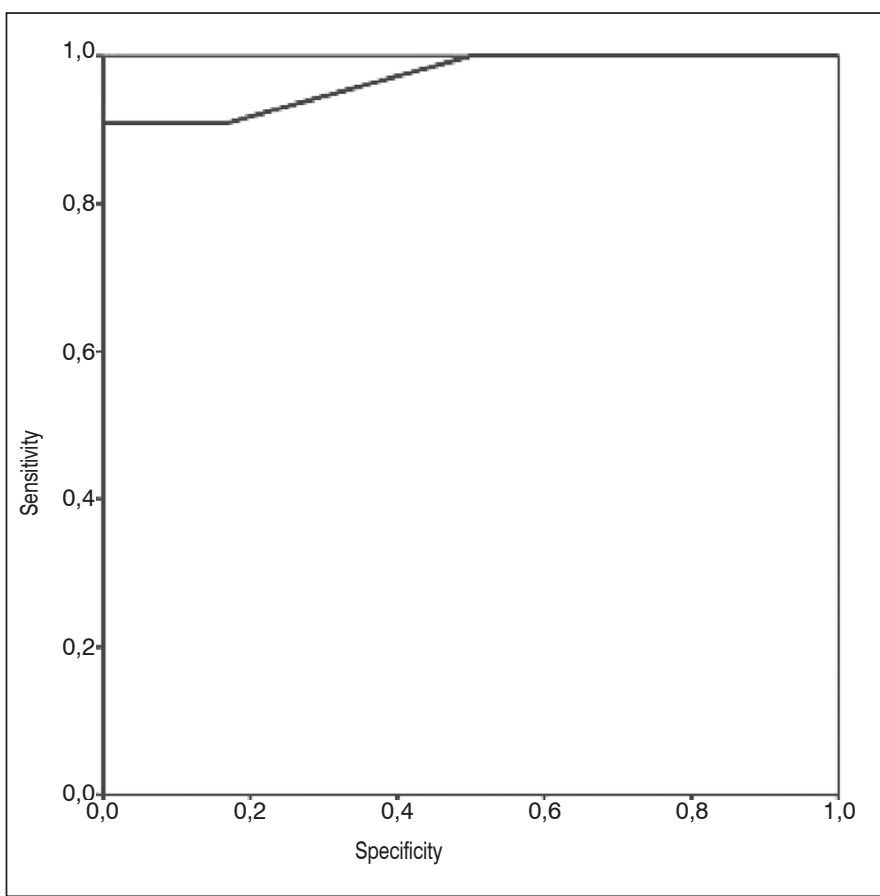

Figure 3. ROC curve of the SDI to discriminate the quality of life categories.
Table 7. Values of the area of the ROC curve of the SDI in relation to the quality of life categories, established cutoff, and the respective sensitivity and specificity values of the cutoff.

\begin{tabular}{c|c|c|c|c|c}
\hline \multirow{2}{*}{ Area } & \multicolumn{2}{|c|}{ Cl 95\% } & \multirow{2}{*}{ Cutoff } & Sensitivity & \multirow{2}{*}{ Specificity } \\
\cline { 2 - 4 } & Inferior & Superior & & & \\
\hline 0.970 & 0.896 & 1.000 & 5.5 & 90.9 & 100 \\
\hline
\end{tabular}

\section{DISCUSSION}

This study evaluated patients with insufficiency fractures of the proximal femur, but who had no prior knowledge of pathologies of the spine. The quality of life/disability questionnaire showed that all the study patients had significant complaints in relation to the spine (severe and very severe disability) prior to the femoral fracture event and that all of them had some degree of spinal fracture. Despite the relatively small number of patients in the study, the higher proportion of insufficiency hip fractures in the women than in the men corroborates the literature figures of around $60 \%$ $70 \%$ of fractures in female patients, as does the average age of occurrence of the event. ${ }^{20}$

The study was conducted in a tertiary public university hospital, where a large percentage of the cases treated are patients in unfavorable economic conditions, often with limited access to basic and preventative health services. This is demonstrated in our study by the fact that none of the patients, all of whom had osteoporotic fractures, had been either diagnosed with or had undergone any therapy for this pathology, which conforms with Marques Neto JF et al., ${ }^{21}$ who state that only one in every three people with osteoporosis is diagnosed and, of these, only one in five receive any kind of treatment.

It is known that the presence of subclinical or clinically symptomatic insufficiency fractures in the spine disrupts the daily lives of patients by having a direct negative impact on their mental and social health profiles, as shown by the worsening of the quality of life indices in these patients. ${ }^{15-17,22,23}$ This information agrees with that found in our study through the application of the Oswestry Disability Index in which patients had severe or very severe disability related to the spine prior to the appendicular fracture. This fact must be taken seriously, as these patients already had vertebral fractures prior to the fracture of the femur. The diagnosis, monitoring, and effective treatment of pre-existing osteoporosis could have interfered positively with the evolution of the appendicular fractures and may have even prevented the hip fractures, which together with the spinal fractures, result in mortality rates of $20 \%$ in one year, possibly reaching as high as $50 \%$ over three years. ${ }^{1,15}$

This study showed clearly that the evaluation method proposed by Gennant et al. ${ }^{17}$ is useful for the identification of vertebral fractures from thoracolumbar insufficiency. We found a high prevalence of vertebral insufficiency fractures in the patients with fractures of the proximal femur, $100 \%$ in our study, a finding that agrees with Castro et al. ${ }^{23}$

Even though the correlation of sex with quality of life did not yield a statistically significant value, our findings suggest that the male patients have a better quality of life score than the female patients, as evidenced by the lower ODI scores. The deterioration of the quality of life in women with osteoporotic fractures is well documented in the literature, however there is little information on this issue with respect to the male population, even though it is known that the progress of patients with osteoporotic fractures tends to be worse in men. ${ }^{24,25}$ This finding may be due to the relatively low number of patients included in the case series in our study.

The correlation between patient age and the SDI fracture score only showed statistical significance in T7, that is, the older the patient the greater the probability of a fracture in this vertebra, but there is no supporting evidence of this finding in the literature, nor 
for the statistically significant inverse correlation between the finding of fractures in L3 and a worse evolution score in the ODI. The latter finding could be an indication of the fact that $L 3$ is generally located at the apex of the lumbar lordosis.

There was a statistically significant inverse correlation between the SDI and Oswestry scores, i.e. the higher the SDI the better the ODI result. This could be related to the fact that lower SDI indices are linked to more recent compression fractures, which can manifest themselves in a more symptomatic manner, among other factors, because the body has not yet made any postural adaptation and that no adequate and timely treatment has been instituted, leading to the deterioration of the quality of life of the patient. This can be added to the information published in the study of Roux et al. ${ }^{8}$ in which, when the SDI score is higher than five, the risk of new fractures increases considerably. When the score is higher than eight, the risk of new fractures plateaus. This is because 13 vertebrae (T4 to L4) are evaluated, so it is natural that at some point, there will be no more vertebrae to be fractured.

Analyzing whether there is a cutoff for the SDI value that discri-

Attachment 1. Oswestry Disability Index.

\begin{tabular}{|c|c|}
\hline \multicolumn{2}{|c|}{ Oswestry Disability Index 2.0} \\
\hline \multicolumn{2}{|c|}{$\begin{array}{c}\text { Consider how much the "back (or leg) problem" has affected your day-to-day } \\
\text { in the following questions: }\end{array}$} \\
\hline 1 - Pain intensity & 6 - Standing \\
\hline 2 - Personal care & 7 - Sleeping \\
\hline 3 - Lifting weights & $8-$ Sex life \\
\hline 4 - Walking & 9 - Social life \\
\hline 5 - Sitting & 10 - Travel \\
\hline \multicolumn{2}{|c|}{ Interpretation of the Oswestry Index results. } \\
\hline \multicolumn{2}{|c|}{$0 \%$ to $20 \%$ - Minimal disability } \\
\hline \multicolumn{2}{|c|}{$21 \%$ to $40 \%$ - Moderate disability } \\
\hline \multicolumn{2}{|c|}{$41 \%$ to $60 \%$ - Severe disability } \\
\hline \multicolumn{2}{|c|}{$61 \%$ to $80 \%$ - Very serious disability } \\
\hline \multicolumn{2}{|c|}{$81 \%$ to $100 \%$ - Exaggerated symptoms } \\
\hline
\end{tabular}

\section{REFERENCES}

1. Rachner TD, Khosla S, Hofbauer LC. Osteoporosis: now and the future. Lancet. 2011:377(9773):1276-87.

2. Kanis JA, McCloskey EV, Johansson H, Cooper C, Rizzoli R, Reginster JY, et al. European guidance for the diagnosis and management of osteoporosis in postmenopausal women. Osteoporos Int. 2013;24(1):23-57.

3. Silverman SL. Quality-of-life issues in osteoporosis. Curr Rheumatol Rep. 2005;7(1):39-45.

4. Melton LJ 3rd, Chrischilles EA, Cooper C, Lane AW, Riggs BL. Perspective. How many women have osteoporosis? J Bone Miner Res. 1992;7(9):1005-10.

5. Lips P. Epidemiology and predictors of fractures associated with osteoporosis. Am J Med. 1997;103(2A):3S-8S.

6. Burge R, Dawson-Hughes B, Solomon DH, Wong JB, King A, Tosteson A. Incidence and economic burden of osteoporosis-related fractures in the United States, 2005-2025. J Bone Miner Res. 2007;22(3):465-75.

7. Office of the Surgeon General (US). Bone Health and Osteoporosis: A Report of the Surgeon General. Rockville (MD): Office of the Surgeon General (US); 2004.

8. Roux C, Fechtenbaum J, Kolta S, Briot K, Girard M. Mild prevalent and incident vertebral fractures are risk factors for new fractures. Osteoporos Int. 2007;18(12):1617-24.

9. Gehlbach SH, Bigelow C, Heimisdottir M, May S, Walker M, Kirkwood JR. Recognition of vertebral fracture in a clinical setting. Osteoporos Int. 2000:11(7):577-82.

10. Grigoryan M, Guermazi A, Roemer FW, Delmas PD, Genant HK. Recognizing and reporting osteoporotic vertebral fractures. Eur Spine J. 2003;12(Suppl 2):S104-12.

11. Kerkeni S, Kolta S, Fechtenbaum J, Roux C. Spinal deformity index (SDI) is a good predictor of incident vertebral fractures. Osteoporos Int. 2009;20(9):1547-52.

12. Lindsay R, Silverman SL, Cooper C, Hanley DA, Barton I, Broy SB, et al. Risk of new vertebral fracture in the year following a fracture. JAMA. 2001;285(3):320-3.

13. Dreinhöfer KE, Féron JM, Herrera A, Hube R, Johnell O, Lidgren L, et al. Orthopaedic surgeons and fragility fractures. A survey by the Bone and Joint Decade and the International Osteoporosis Foundation. J Bone Joint Surg Br. 2004;86(7):958-61. minates the quality of life categories, we arrived at a value of 5.5 , at which the ROC curve was $97 \%$, providing sensitivity of $90.9 \%$ and specificity of $100 \%$, i.e. patients with SDI scores greater than 5.5 tend to present worse ODI indices.

\section{CONCLUSION}

Patients with fractures of the proximal femur show significant changes in the quality of their lives when their complaints related to the spine prior to the femoral fracture are investigated, and the spine should be systematically investigated in these patients. These complaints can and should be an alert for the diagnosis and treatment of osteoporosis at an early stage with the goal of trying to minimize the chances of occurrence of other fractures and of the increase in morbimortality inherent in this disease.

All authors declare no potential conflict of interest concerning this article.
14. Cummings SR, Melton LJ. Epidemiology and outcomes of osteoporotic fractures. Lancet. 2002:359(9319):1761-7.

15. Johnell O, Kanis JA, Odén A, Sernbo I, Redlund-Johnell I, Petterson C, et al. Mortality after osteoporotic fractures. Osteoporos Int. 2004;15(1):38-42.

16. Fairbank JC, Pynsent PB. The Oswestry Disability Index. Spine (Phila Pa 1976) 2000;25(22):2940-52

17. Genant HK, Wu CY, van Kuijk C, Nevitt MC. Vertebral fracture assessment using a semiquantitative technique. J Bone Miner Res. 1993:8(9):1137-48.

18. Guglielmi G, Diacinti D, van Kuijk C, Aparisi F, Krestan C, Adams JE, et al. Vertebral morphometry: current methods and recent advances. Eur Radiol. 2008;18(7):1484-96.

19. Kirkwood BR, Sterne JAC. Essential medical statistics. 2nd ed. Massachusetts: Blackwell Science; 2006

20. Kannus $P$, Parkkari J, Sievänen $H$, Heinonen A, Vuori I, Järvinen M. Epidemiology of hip fractures. Bone. 1996;18(1 Suppl):57S-63S.

21. Marques-Neto JF, Lederman R. Osteoporose: Brasil ano 2000. 1a ed. São Paulo: Limay; 1995.

22. Oleksik AM, Ewing S, Shen W, van Schoor NM, Lips P. Impact of incident vertebral fractures on health related quality of life (HRQOL) in postmenopausal women with prevalent vertebral fractures. Osteoporos Int. 2005;16(8):861-70

23. Castro GGF, Risso MIN, Zuiani GR, Cavali PTM, Belangero WD, Veiga IG et al. Fraturas vertebrais em pacientes tratados de fraturas do terço proximal do fêmur. Coluna/Columna 2014;13(3):229-31

24. Zwart M, Azagra R, Encabo G, Aguye A, Roca G, Güell S, et al. Measuring health-related quality of life in men with osteoporosis or osteoporotic fracture. BMC Public Health. 2011;11:775.

25. Solimeo SL, Silverman SL, Calderon AD, Nguyen A, Gold DT. Measuring health-related quality of life (HRQOL) in osteoporotic males using the Male OPAQ. Osteoporos Int. 2012;23(3):841-52 